\title{
Protective Effect of an Isoflavone, Tectorigenin, Against Oxidative Stress-induced Cell Death via Catalase Activation
}

ORIGINAL

ARTICLE

\author{
Rui Zhang ${ }^{1,2, *}$, Mei Jing Piao ${ }^{1, *}$, Min Chang Oh $^{1}$, Jeong Eon Park ${ }^{1}$, Kristina Shilnikova ${ }^{1}$, Yu Jin Moon ${ }^{1}$, Dong Hyun Kim ${ }^{3}$, \\ Uhee Jung ${ }^{4}$, In Gyu Kim ${ }^{5,6}$, Jin Won Hyun ${ }^{1}$ \\ 'Department of Biochemistry, Jeju National University School of Medicine, Jeju, Korea, ${ }^{2}$ School of Medical Science and Laboratory Medicine, Jiangsu \\ University, Jiangsu, China, ${ }^{3}$ Department of Microbial Chemistry, College of Pharmacy, Kyung Hee University, Seoul, ${ }^{4}$ Radiation Biotechnology \\ Research Division, Korea Atomic Energy Research Institute, Jeongeup, ${ }^{5}$ Department of Radiation Biology, Environmental Radiation Research Group, \\ Korea Atomic Energy Research Institute, Daejeon, ${ }^{6}$ Department of Radiation Biotechnology and Applied Radioisotope, Korea University of Science \\ and Technology, Daejeon, Korea
}

\begin{abstract}
Background: Isoflavones are biologically active compounds that occur naturally in a variety of plants, with relatively high levels in soybean Tectorigenin, an isoflavone, protects against hydrogen peroxide $\left(\mathrm{H}_{2} \mathrm{O}_{2}\right)$-induced cell damage. However, the underlying mechanism is unknown.

Methods: The MTT assay was performed to determine cell viability. Catalase activity was assessed by determining the amount of enzyme required to degrade $1 \mu \mathrm{M} \mathrm{H}_{2} \mathrm{O}_{2}$. Protein expression of catalase, phospho-extracellular signal-regulated kinase (ERK), IKB- $\alpha$, and NF-KB were evaluated by Western blot analysis. A mobility shift assay was performed to assess the DNA-binding ability of NF-KB. Transient transfection and a NF-kB luciferase assay were performed to assess transcriptional activity.

Results: Tectorigenin reduced $\mathrm{H}_{2} \mathrm{O}_{2}$-induced death of Chinese hamster lung fibroblasts (V79-4). In addition, tectorigenin increased the activity and protein expression of catalase. Blockade of catalase activity attenuated the protective effect of tectorigenin against oxidative stress. Furthermore, tectorigenin enhanced phosphorylation of ERK and nuclear expression of NF-KB, while inhibition of ERK and NF-KB attenuated the protective effect of tectorigenin against oxidative stress.
\end{abstract}

Conclusions: Tectorigenin protects cells against oxidative damage by activating catalase and modulating the ERK and NF-KB signaling pathway.

(J Cancer Prev 2016;21:257-263)

Key Words: Isoflavones, Tectorigenin, Catalase, Extracellular signal regulated kinases, NF-kappa B

\section{INTRODUCTION}

Isoflavones are plant-derived, biologically active compounds that are commonly used as natural drugs or dietary supplements. Due to their multiple biological activities, isoflavones became the subject of intensive studies as potential phytotherapeutic compounds. An isoflavone, tectorigenin, shows potent hypoglycemic activity, anticancer effects, tyrosinase inhibitory activity, and anaphylaxis inhibitory activity. ${ }^{1.3}$ In addition, our previous study demonstrated that tectorigenin, a metabolite formed by transformation of tectoridin by intestinal microflora, has a cytoprotective effect against hydrogen peroxide $\left(\mathrm{H}_{2} \mathrm{O}_{2}\right)$-induced cell damage via antioxidant activity. ${ }^{4}$

Oxygen consumption in aerobic cells is accompanied by the generation of reactive oxygen species (ROS) such as $\mathrm{H}_{2} \mathrm{O}_{2}$, superoxide anion, and hydroxyl radicals. Oxidative stress results

Received July 27, 2016, Revised October 11, 2016, Accepted October 15, 2016

Correspondence to: Jin Won Hyun

Department of Biochemistry, Jeju National University School of Medicine, 102 Jejudaehak-ro, Jeju 63243, Korea

Tel: +82-64-754-3838, Fax: +82-64-726-4152, E-mail: jinwonh@jejunu.ac.kr

*These authors contributed equally to this work as co-first authors.

Copyright (C) 2016 Korean Society of Cancer Prevention

(c) This is an Open Access article distributed under the terms of the Creative Commons Attribution Non-Commercial License (http://creativecommons.org/licenses/by-nc/4.0) which permits unrestricted non-commercial use, distribution, and reproduction in any medium, provided the original work is properly cited. 
from ROS and an imbalance in favor of oxidants over antioxidants, which may affect lipids, DNA, carbohydrates, and proteins, ${ }^{5}$ and thus contributes to inflammation, aging, cancer, arteriosclerosis, hypertension, and diabetes. ${ }^{6-11}$

Cells have developed a variety of antioxidant defense mechanisms for cytoprotection against ROS. Catalase is located in the peroxisome and converts $\mathrm{H}_{2} \mathrm{O}_{2}$ into molecular oxygen and water. ${ }^{12}$ Catalase plays an important role in protection against oxidative stress-induced cell damage. ${ }^{13-17}$ In addition, catalase regulates cell growth by activating the extracellular signal-regulated kinase (ERK) and consequently stimulates cell growth, which is inhibited by oxidative stress. ${ }^{18,19}$ The transcription factor $\mathrm{NF}-\mathrm{\kappa B}$ is implicated in multiple physiological and pathological processes, and regulates gene expression important for mediating stress responses, including cell proliferation, differentiation, inflammation, apoptosis, and cell survival. ${ }^{20,21}$ Overexpression of NF- $\mathrm{KB}$ results in increased cell viability by blocking apoptosis. ${ }^{22}$ Although tectorigenin has protective effects against $\mathrm{H}_{2} \mathrm{O}_{2}$-induced oxidative stress, ${ }^{4}$ the underlying mechanism has not been elucidated.

Therefore, the present study investigated the mechanisms by which tectorigenin protects against $\mathrm{H}_{2} \mathrm{O}_{2}$-induced oxidative stress in terms of NF-KB and ERK.

\section{MATERIALS AND METHODS}

\section{Reagents}

Tectorigenin (Fig. 1A) was provided by Professor Dong Hyun Kim (Kyung Hee University, Seoul, Korea). MTT, 3-amino-1,2,4-triazole (ATZ), and BAY 11-7082 ((E)-3-(4-methylphenylsulfonyl)-2-propenenitrile) were purchased from Sigma-Aldrich (St. Louis, MO, USA). An anti-catalase antibody was purchased from Biodesign International Company (Saco, ME, USA). Anti-ERK2 and anti-phospho-ERK1/2 (Thr 202/Tyr 204) antibodies were purchased from Cell Signaling Technology (Beverly, MA, USA). U0126 was purchased from Calbiochem (San

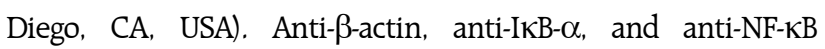
antibodies were purchased from Santa Cruz Biotechnology, Inc. (Dallas, TX, USA). A primary antibody against TATA-binding protein was purchased from Abcam (Cambridge, MA, USA). The NF-אB-binding site-luciferase construct was a generous gift from Dr. Young Joon Surh (Seoul National University, Seoul, Korea). The other chemicals and reagents were of analytical grade.

\section{Cell culture}

Chinese hamster lung fibroblasts (V79-4) from the American
Type Culture Collection were maintained at $37^{\circ} \mathrm{C}$ in an incubator in a humidified atmosphere of $5 \% \mathrm{CO}_{2}$ and cultured in Dulbecco's modified Eagle's medium containing 10\% heat-inactivated fetal calf serum, streptomycin (100 $\mu \mathrm{g} / \mathrm{mL}$ ), and penicillin (100 units $/ \mathrm{mL}$ ).

\section{Cell viability}

The cytoprotective effect of tectorigenin against $\mathrm{H}_{2} \mathrm{O}_{2}$-treated cell death was determined by assessing cell viability using the MTT assay. ${ }^{23}$ MTT solution was added to each well and incubated for 4 hours. The formazan crystals in each well were dissolved in dimethylsulfoxide, and absorbance at $540 \mathrm{~nm}$ was read on a scanning multi-well spectrophotometer.

\section{Catalase activity}

Cells were seeded in a culture dish at a density of $1.5 \times 10^{5}$ cells $/ \mathrm{mL}$. At 16 hours after plating, the cells were treated with 10 $\mu \mathrm{g} / \mathrm{mL}$ tectorigenin for 3, 6, 12, and 24 hours. The harvested cells were suspended in $10 \mathrm{mM}$ phosphate buffer ( $\mathrm{pH}$ 7.5) and then lysed on ice by sonication twice for 15 seconds. The lysates were then supplemented with Triton X-100 (1\%) and incubated for 10

A<smiles>COc1c(O)cc2occ(-c3ccc(O)cc3)c(=O)c2c1O</smiles>

B

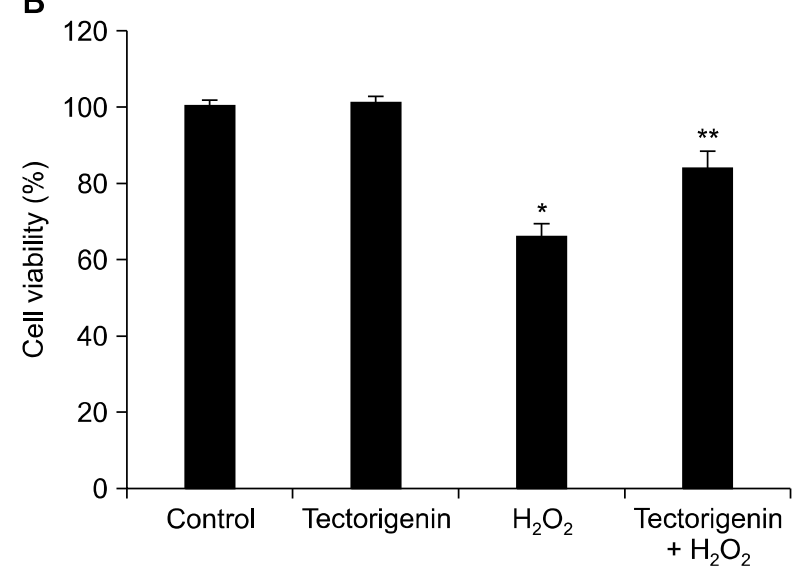

Figure 1. Protective effect of tectorigenin against $\mathrm{H}_{2} \mathrm{O}_{2}$-induced cell damage. (A) The chemical structure of tectorigenin. (B) The viability of V79-4 cells following $\mathrm{H}_{2} \mathrm{O}_{2}$ treatment was determined by the MTT assay. *Significantly different from control cells $(P<0.05)$. ${ }^{*}$ Significantly different from $\mathrm{H}_{2} \mathrm{O}_{2}$-treated cells $(P<0.05)$. 
minutes on ice. The lysates were centrifuged at $5,000 \times g$ for 30 minutes at $4^{\circ} \mathrm{C}$ to remove cellular debris. The protein content of the supernatant was determined by the Bradford method, and the supernatants were added to $50 \mathrm{mM}$ phosphate buffer ( $\mathrm{pH}$ 7.0) containing $100 \mathrm{mM} \mathrm{H}_{2} \mathrm{O}_{2}$. The reaction mixture was incubated for 2 minutes at $37^{\circ} \mathrm{C}$, and absorbance at $240 \mathrm{~nm}$ was monitored for 5 minutes. The change in absorbance over time was proportional to the degradation of $\mathrm{H}_{2} \mathrm{O}_{2} .{ }^{24}$ Catalase activity was expressed as units/mg protein, and one unit of enzyme activity was defined as the amount of enzyme required to degrade $1 \mu \mathrm{M} \mathrm{H}_{2} \mathrm{O}_{2}$.

\section{Western blot analysis}

Cells were harvested and washed twice with phosphate-buffered saline. The harvested cells were then lysed on ice for 30 minutes in $100 \mu \mathrm{L}$ of lysis buffer $(120 \mathrm{mM} \mathrm{NaCl}, 40 \mathrm{mM}$ Tris [pH 8 , and $0.1 \% \mathrm{NP} 40$ ) and centrifuged at $13,000 \times g$ for 15 minutes. Supernatants were collected and the protein concentrations were determined. Aliquots of the lysates ( $40 \mu \mathrm{g}$ of protein) were electrophoresed in a $10 \%$ SDS-polyacrylamide gel. Proteins in the gels were transferred to nitrocellulose membranes (Bio-Rad, Hercules, CA, USA), which were then incubated with anti-catalase, anti-ERK2, anti-phospho-ERK1/2, anti-IKB- $\alpha$, and anti-NF- $\mathrm{KB}$ primary antibodies. The membranes were further incubated with secondary immunoglobulin G-horseradish peroxidase conjugates (Pierce, Rockland, IL, USA), and protein bands were detected using an enhanced chemiluminescence Western blotting detection kit (Amersham, Little Chalfont, Buckinghamshire, UK) and then exposed to $\mathrm{x}$-ray film.

\section{Transient transfection and NF- $\kappa B$ luciferase assay}

Cells were transiently transfected with the plasmid harboring the NF- $\mathrm{KB}$ promoter using 1,2-Dioleoyloxy-3-trimethylammonium propane chloride as the transfection reagent, according to the manufacturer's instructions (Roche, Mannheim, Germany). Following transfection overnight, the cells were treated with 10 $\mu \mathrm{g} / \mathrm{mL}$ tectorigenin for the indicated durations. The cells were then washed twice with phosphate-buffered saline and lysed with reporter lysis buffer (Promega, Madison, WI, USA). Following vortex mixing and centrifugation at $12,000 \times g$ for 1 minute at $4^{\circ} \mathrm{C}$, the supernatant was stored at $-70^{\circ} \mathrm{C}$ for the luciferase assay. After mixing $20 \mu \mathrm{L}$ of the cell extract with $100 \mu \mathrm{L}$ of the luciferase assay reagent at room temperature, the mixture was placed in an illuminometer to measure the light produced.

\section{Electrophoretic mobility shift assay}

Cells were harvested and subsequently lysed on ice with $1 \mathrm{~mL}$ of lysis buffer (10 mM Tris-HCl [pH 7.9], $10 \mathrm{mM} \mathrm{NaCl}, 3 \mathrm{mM}$ $\mathrm{MgCl}_{2}$, and $1 \% \mathrm{NP}-40$ ) for 4 minutes. After centrifugation at 3,000 $\times g$ for 10 minutes, the pellets were re-suspended in $50 \mu \mathrm{L}$ of extraction buffer (20 mM HEPES [pH 7.9], 20\% glycerol, $1.5 \mathrm{mM}$ $\mathrm{MgCl} 2,0.2 \mathrm{mM}$ EDTA, $1 \mathrm{mM}$ dithiothreitol [DTT], and $1 \mathrm{mM}$ phenylmethane sulfonyl fluoride), incubated on ice for 30 minutes, and centrifuged at $13,000 \times g$ for 5 minutes. The supernatant (nuclear protein) was stored at $-70^{\circ} \mathrm{C}$ after determining the protein concentration. Oligonucleotides containing the NF- $\mathrm{KB}$ consequence sequence (5'-AGT TGA GGG GAC TTT CCC AGGC-3') were annealed, labeled with $\left[\gamma^{32} \mathrm{P}\right]$ ATP using $\mathrm{T} 4$ polynucleotide kinase, and used as probes. The probes were incubated with the nuclear extracts at $4^{\circ} \mathrm{C}$ for 30 minutes in a final volume of $20 \mu \mathrm{L}$ containing $12.5 \%$ glycerol, $12.5 \mathrm{mM}$ HEPES (pH 7.9), 4 mM Tris-HCl (pH 7.9), 60 mM KCl, 1 mM EDTA, and 1 $\mathrm{mM}$ DTT together with $1 \mathrm{mg}$ of poly (dI-dC). Binding products were resolved on a $5 \%$ polyacrylamide gel, and the bands were visualized by autoradiography. ${ }^{25}$

\section{Statistical analysis}

All measurements were made in triplicate and all values represent means $\pm \mathrm{SE}$. The results were subjected to an analysis of the variance using Tukey's test to analyze the differences. $P<$ 0.05 was considered significant.

\section{RESULTS}

\section{Effect of tectorigenin on cell damage induced by hydrogen peroxide}

The protective effect of tectorigenin against $\mathrm{H}_{2} \mathrm{O}_{2}$-induced cell death was measured using the MTT test. Cells were treated with $10 \mu \mathrm{g} / \mathrm{mL}$ tectorigenin for 1 hour prior to the addition of $\mathrm{H}_{2} \mathrm{O}_{2}$, and cell viability was determined 24 hours later by the MTT assay. Treatment with tectorigenin increased cell viability to $84 \%$ compared with $66 \%$ for $\mathrm{H}_{2} \mathrm{O}_{2}$-treated cells (Fig. 1B), indicating that tectorigenin protected against cell damage induced by $\mathrm{H}_{2} \mathrm{O}_{2}$ treatment.

\section{Effect of tectorigenin on catalase}

To investigate whether the cytoprotective effect of tectorigenin against oxidative stress was associated with the activation of antioxidant enzymes, catalase activity was measured in tectorigenin-treated cells. Catalase activity was increased by tectorigenin in a time-dependent manner and reached $28 \mathrm{U} / \mathrm{mg}$ protein at 24 hours (Fig. 2A). The expression of catalase protein by tectorigenin was determined by Western blot analysis. In the 


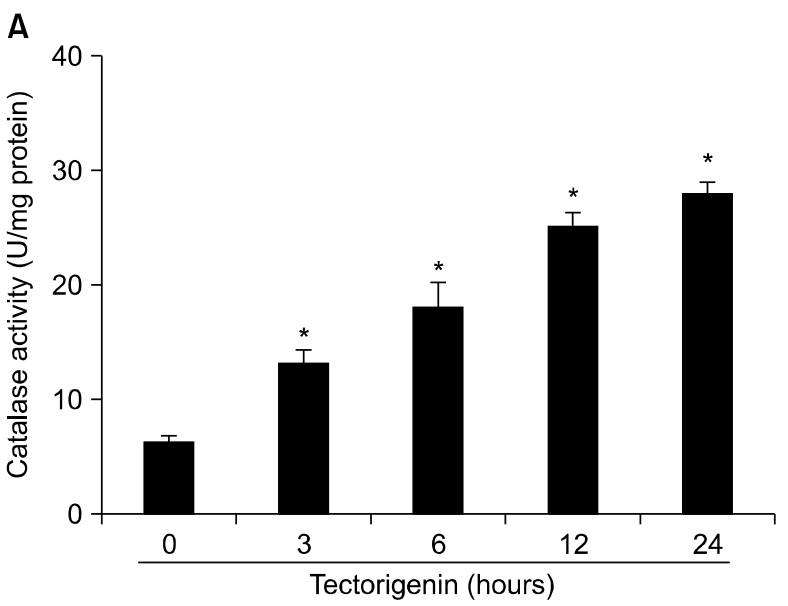

B

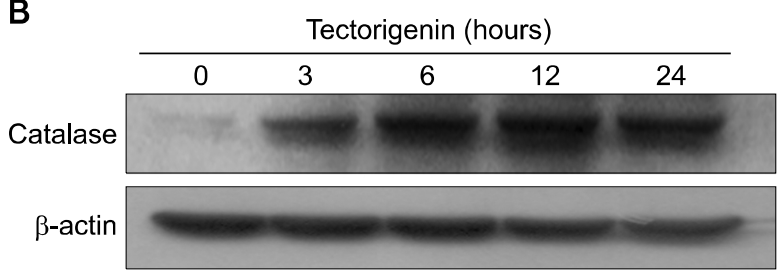

C

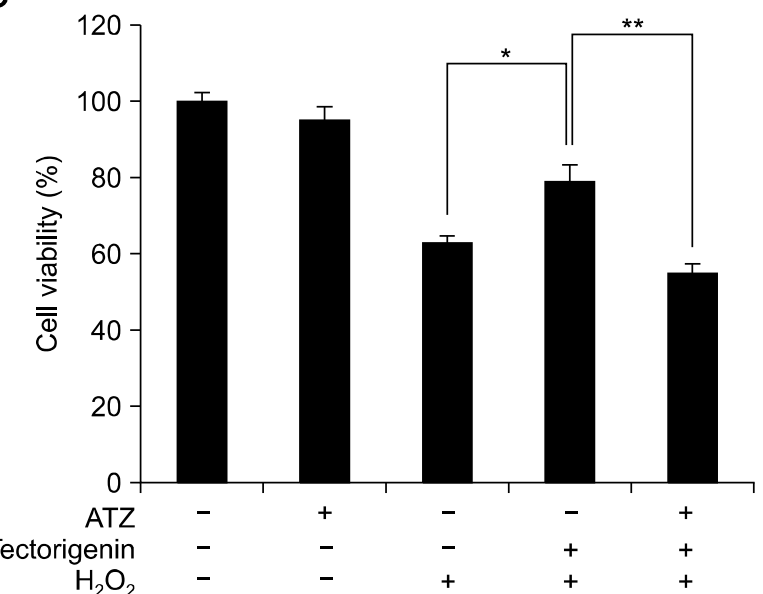

Figure 2. Effect of tectorigenin on catalase. (A) Catalase activity is expressed as the average number of enzyme units per milligram of protein $\pm \mathrm{SE}$. *Significantly different from control cells $(P<0.05)$. (B) Cell lysates were electrophoresed and expression of catalase was detected using a specific antibody. (C) After treatment with 3-amino-1,2,4-triazole (ATZ), tectorigenin, and/or $\mathrm{H}_{2} \mathrm{O}_{2}$, cell viability was determined by the MTT assay. *Significantly different from $\mathrm{H}_{2} \mathrm{O}_{2}$-treated cells $(P<0.05)$. ${ }^{*}$ Significantly different from tectorigenin plus $\mathrm{H}_{2} \mathrm{O}_{2}$-treated cells $(P<0.05)$.

presence of tectorigenin, protein expression of catalase was increased within 24 hours (Fig. 2B). To confirm the effect of catalase in tectorigenin-induced cytoprotection against $\mathrm{H}_{2} \mathrm{O}_{2}$-induced damage, cells were pre-treated with $20 \mathrm{mM} \mathrm{ATZ}$, a specific inhibitor of catalase, ${ }^{26}$ for 30 minutes, followed by incubation
A

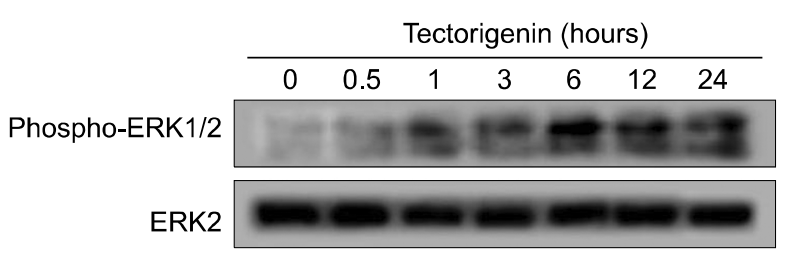

B

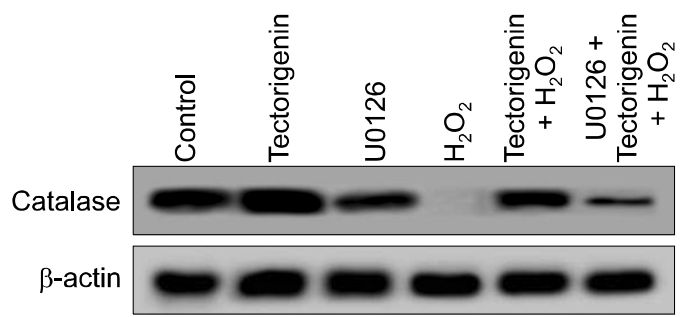

C

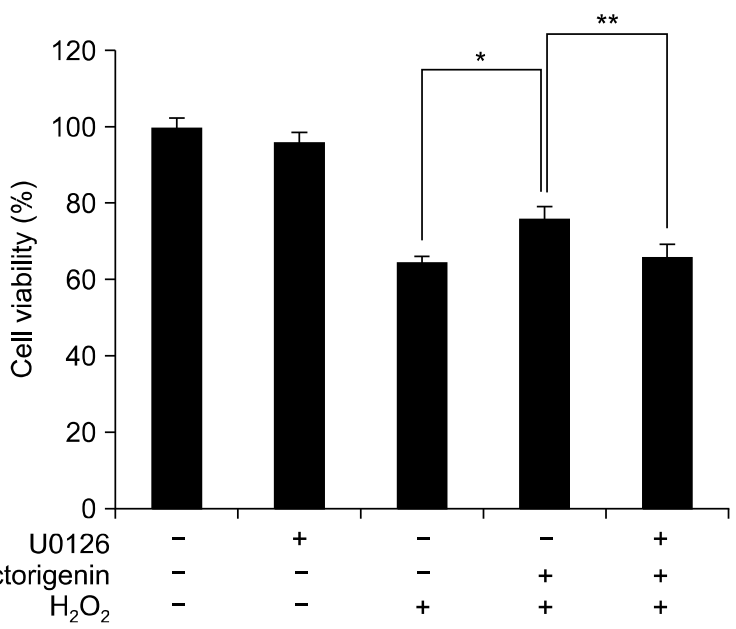

Figure 3. Effect of tectorigenin on extracellular signal-regulated kinase (ERK) activity. (A) Cell lysates were electrophoresed and phospho-ERK1/2 and ERK2 were detected using specific antibodies. (B) After treatment with U0126, tectorigenin, and/or $\mathrm{H}_{2} \mathrm{O}_{2}$, catalase expression was detected using a specific antibody and (C) cell viability was determined by the MTT assay. *Significantly different from $\mathrm{H}_{2} \mathrm{O}_{2}$-treated cells $(P<0.05)$. **Significantly different from tectorigenin plus $\mathrm{H}_{2} \mathrm{O}_{2}$-treated cells $(P<0.05)$.

with tectorigenin for 30 minutes and exposure to $1 \mathrm{mM} \mathrm{H}_{2} \mathrm{O}_{2}$ for 24 hours. ATZ treatment abolished the protective effect of tectorigenin in $\mathrm{H}_{2} \mathrm{O}_{2}$-damaged cells (Fig. 2C).

\section{Effect of tectorigenin on extracellular signal-regulated kinase and NF-KB}

The expression and activity of catalase are increased via ERK and the transcription factor NF-KB. ${ }^{27}$ To better understand the mechanism underlying the protective effect of tectorigenin, activation of ERK was examined by Western blotting with a phospho-ERK-specific antibody. Tectorigenin markedly induced 
A

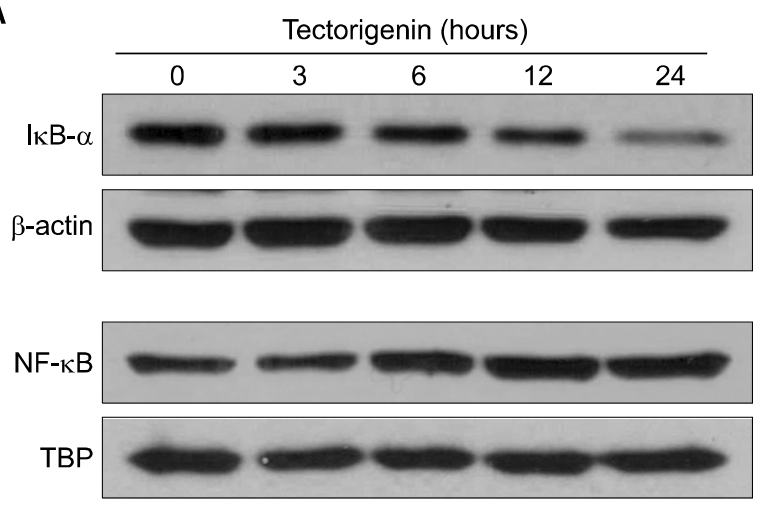

B

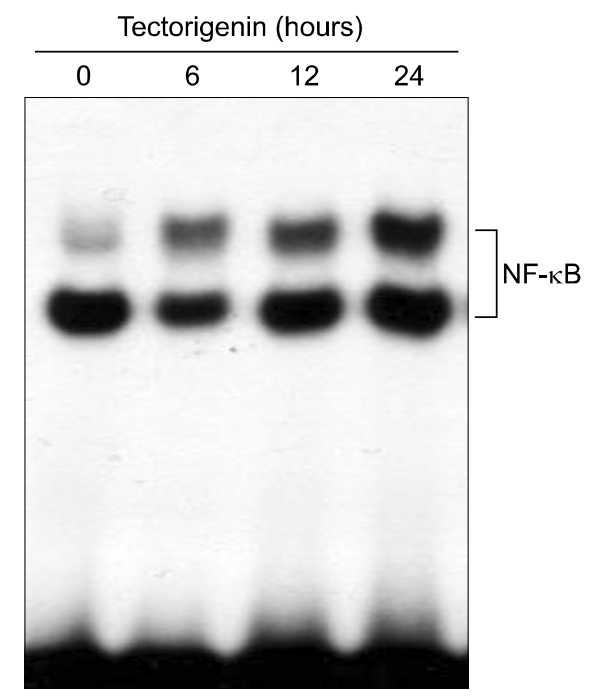

C

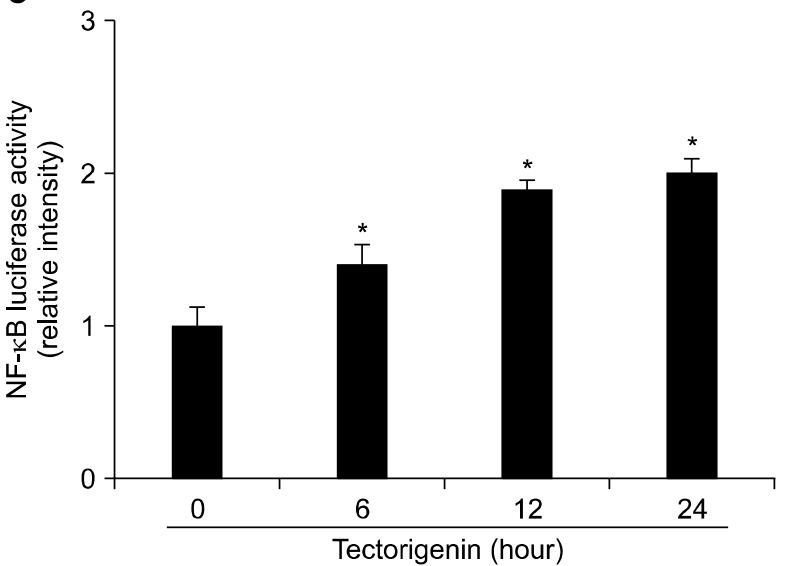

D

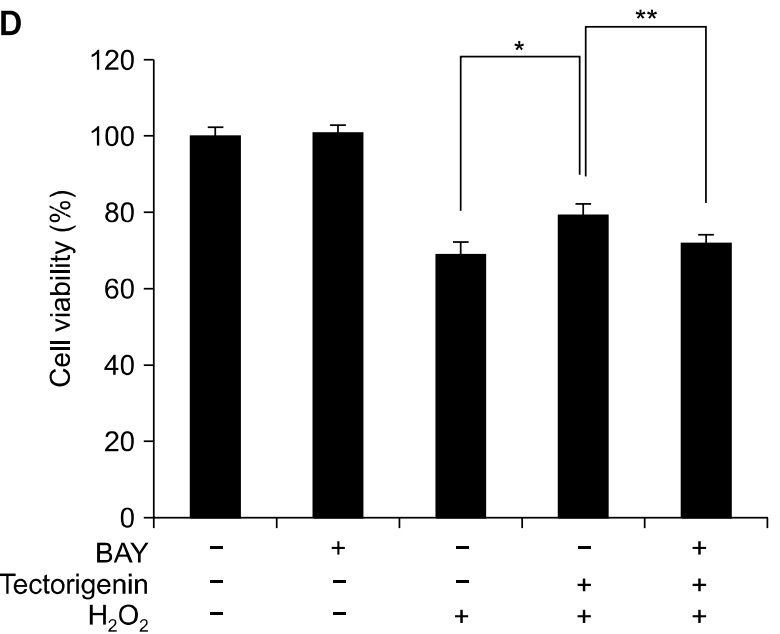

Figure 4. Effect of tectorigenin on NF-KB activity. (A) Cytosolic IKB- $\alpha$ and nuclear NF-KB (p65) from tectorigenin-treated cells were detected using specific antibodies. $\beta$-actin and TATA-binding protein (TBP) were used as loading controls for the cytosolic and nuclear fractions, respectively. (B) The DNA-binding activity of NF-KB from tectorigenin-treated cells was detected using an electrophoretic mobility shift assay. (C) The transcriptional activity of NF-KB in tectorigenin-treated cells was assessed using a NF-KB-binding site-luciferase construct. *Significantly different from control cells $(P<0.05)$. (D) After treatment with BAY 11-7082, tectorigenin, and/or $\mathrm{H}_{2} \mathrm{O}_{2}$, cell viability was determined by the MTT assay. *Significantly different from $\mathrm{H}_{2} \mathrm{O}_{2}$-treated cells $(P<0.05)$. **Significantly different from tectorigenin plus $\mathrm{H}_{2} \mathrm{O}_{2}$-treated cells $(P<0.05)$.

phosphorylation of ERK (Fig. 3A). However, there was no change in the ERK2 protein level. In addition, to determine the effect of an ERK inhibitor on catalase expression, cells were pre-treated for 30 minutes with U0126 (10 nM), a specific inhibitor of ERK, followed by incubation with tectorigenin for 30 minutes and exposure to $1 \mathrm{mM} \mathrm{H}_{2} \mathrm{O}_{2}$ for 24 hours. U0126 treatment attenuated expression of catalase, which was protected by tectorigenin treatment in $\mathrm{H}_{2} \mathrm{O}_{2}$-damaged cells (Fig. 3B). Furthermore, to determine the effect of the ERK inhibitor on tectorigenin-mediated protection against $\mathrm{H}_{2} \mathrm{O}_{2}$-induced damage, cells were pre-treated with the ERK inhibitor for 30 minutes, followed by incubation with tectorigenin for 30 minutes and exposure to $1 \mathrm{mM} \mathrm{H}_{2} \mathrm{O}_{2}$ for 24 hours. U0126 treatment abolished the protective effect of tectorigenin in $\mathrm{H}_{2} \mathrm{O}_{2}$-damaged cells (Fig. 3C). These data suggested that the cytoprotective effect of tectorigenin involves activation of the ERK pathway.

We next determined whether tectorigenin activated NF- $\mathrm{KB}$. Tectorigenin treatment enhanced nuclear NF-KB level and decreased IKB- $\alpha$ protein expression in the cytosol (Fig. 4A). NF-KB activation in tectorigenin-treated cells was assessed by the electrophoretic mobility shift assay with an oligonucleotide harboring a consensus NF-KB-binding element. Tectorigenin-treated cells exhibited a high level of NF-KB binding (Fig. 4B). The transcriptional activity of NF- $\mathrm{KB}$ was also assessed using a promoter construct containing the NF-KB-binding DNA consensus site linked to a luciferase reporter gene. Tectorigenin 
increased the transcriptional activity of NF- $\mathrm{KB}$ (Fig. 4C). To determine the effect of a NF- $\mathrm{KB}$ inhibitor on the protective effect of tectorigenin against $\mathrm{H}_{2} \mathrm{O}_{2}$-induced damage, cells were pre-treated for 30 minutes with BAY 11-7082 (1 $\mu \mathrm{M})$, a NF-kB-specific inhibitor, followed by incubation with tectorigenin for 30 minutes and exposure to $1 \mathrm{mM} \mathrm{H}_{2} \mathrm{O}_{2}$ for 24 hours. BAY 11-7082 treatment abolished the protective effect of tectorigenin in $\mathrm{H}_{2} \mathrm{O}_{2}$-treated cells (Fig. 4D), indicating that NF- $\mathrm{NB}$ is also involved in the protective effect of tectorigenin against $\mathrm{H}_{2} \mathrm{O}_{2}$-induced cell damage.

\section{DISCUSSION}

Our previous study showed that tectorigenin exerts a cytoprotective effect against $\mathrm{H}_{2} \mathrm{O}_{2}$-induced cell damage. ${ }^{4}$ Catalase effectively improves antioxidant defense mechanisms in cells. In the present study, tectorigenin increased the activity and protein expression of catalase in a time-dependent manner and the protective effect of tectorigenin was abolished by a catalase inhibitor, suggesting that the cytoprotective effect of tectorigenin was modulated by catalase. Antioxidant enzymes may be potential target molecules mediating the anti-apoptotic functions of NF- $\kappa B$ against oxidative stress. Sequence analysis of antioxidant enzymes revealed putative binding sites for NF- $\kappa B^{28}$ The expression and activity of catalase are regulated through the ERK and NF-KB. ${ }^{27}$ Phospho-ERK phosphorylates cytoplasmic and nuclear targets, and participates in proliferation, differentiation, and movement. ${ }^{29}$ Based on these findings, we studied the activation of ERK, which is an important component of intracellular signaling cascades that mediate survival upon oxidative stress. The level of phospho-ERK was increased in tectorigenin-treated cells, and the effect of tectorigenin on catalase expression and its protective activity in $\mathrm{H}_{2} \mathrm{O}_{2}$-damaged cells were abolished upon treatment with a specific inhibitor of ERK. This suggests that the cytoprotective effect of tectorigenin involves activation of the ERK pathway. In addition, NF-KB was activated in tectorigenin-treated cells. Regulation of NF- $\mathrm{KB}$ appears to involve phosphorylation of its subunits (e.g., p65) or

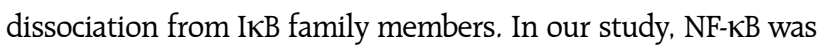
activated by tectorigenin, and treatment with a NF- $\mathrm{KB}$ inhibitor attenuated the cytoprotective effect of tectorigenin.

\section{ACKNOWLEDGMENTS}

This work was supported by National Research Foundation of Korea (NRF) grant funded by Korea government (No.
NRF-2015M2A2A7061657).

\section{CONFLICTS OF INTEREST}

No potential conflicts of interest were disclosed.

\section{REFERENCES}

1. Han T, Cheng G, Liu Y, Yang H, Hu YT, Huang W. In vitro evaluation of tectoridin, tectorigenin and tectorigenin sodium sulfonate on antioxidant properties. Food Chem Toxicol 2012;50:409-14.

2. Qu J, Gao J, Sun J, Zhang L, Makino T, Yuan D. Pharmacokinetics of conjugated metabolites in rat plasma after oral administration of tectoridin. J Chromatogr B Analyt Technol Biomed Life Sci 2012;902:61-9.

3. Liu M, Yang S, Jin L, Hu D, Wu Z, Yang S. Chemical constituents of the ethyl acetate extract of Belamcanda chinensis (L.) DC roots and their antitumor activities. Molecules 2012;17:6156-69.

4. Kang KA, Lee KH, Chae S, Zhang R, Jung MS, Kim SY, et al. Cytoprotective effect of tectorigenin, a metabolite formed by transformation of tectoridin by intestinal microflora, on oxidative stress induced by hydrogen peroxide. Eur J Pharmacol 2005:519:16-23.

5. Lushchak VI. Free radicals, reactive oxygen species, oxidative stresses and their classifications. Ukr Biochem J 2015;87:11-8.

6. Touyz RM. Reactive oxygen species, vascular oxidative stress, and redox signaling in hypertension: what is the clinical significance? Hypertension 2004:44:248-52.

7. Wu KL, Wu CW, Chao YM, Hung CY, Chan JY. Impaired Nrf2 regulation of mitochondrial biogenesis in rostral ventrolateral medulla on hypertension induced by systemic inflammation. Free Radic Biol Med 2016;97:58-74.

8. Li F, Lang F, Zhang H, Xu L, Wang Y, Hao E. Role of TFEB mediated autophagy, oxidative stress, inflammation, and cell death in endotoxin induced myocardial toxicity of young and aged mice. Oxid Med Cell Longev 2016:2016:5380319.

9. Sanz A. Mitochondrial reactive oxygen species: do they extend or shorten animal lifespan? Biochim Biophys Acta 2016;1857: 1116-26.

10. Storz P. KRas, ROS and the initiation of pancreatic cancer [published online ahead of print May 24, 2016]. Small GTPases. doi: 10.1080/21541248.2016.1192714.

11. Diebold L, Chandel NS. Mitochondrial ROS regulation of proliferating cells. Free Radic Biol Med 2016;100:86-93.

12. Del Río LA, López-Huertas E. ROS generation in peroxisomes and its role in cell signaling. Plant Cell Physiol 2016:57:1364-76.

13. Slemmer JE, Shacka JJ, Sweeney MI, Weber JT. Antioxidants and free radical scavengers for the treatment of stroke, traumatic brain injury and aging. Curr Med Chem 2008;15:404-14.

14. Jeong $\mathrm{CH}$, Joo $\mathrm{SH}$. Downregulation of reactive oxygen species in apoptosis. J Cancer Prev 2016;21:13-20.

15. Begara-Morales JC, Sánchez-Calvo B, Chaki M, Valderrama R, Mata-Pérez C, Padilla MN, et al. Antioxidant systems are regulated by nitric oxide-mediated post-translational modifications (NO-PTMs). Front Plant Sci 2016;7:152.

16. Amir Aslani B, Ghobadi S. Studies on oxidants and antioxidants 
with a brief glance at their relevance to the immune system. Life Sci 2016;146:163-73.

17. Han KH, Hashimoto N, Fukushima M. Relationships among alcoholic liver disease, antioxidants, and antioxidant enzymes. World J Gastroenterol 2016:22:37-49.

18. Sen S, Kawahara B, Chaudhuri G. Maintenance of higher $\mathrm{H}_{2} \mathrm{O}_{2}$ levels, and its mechanism of action to induce growth in breast cancer cells: important roles of bioactive catalase and PP2A. Free Radic Biol Med 2012;53:1541-51.

19. Nishikawa M, Hashida M, Takakura Y. Catalase delivery for inhibiting ROS-mediated tissue injury and tumor metastasis. Adv Drug Deliv Rev 2009;61:319-26.

20. Giles KM, Brown RA, Ganda C, Podgorny MJ, Candy PA, Wintle LC, et al. microRNA-7-5p inhibits melanoma cell proliferation and metastasis by suppressing RelA/NF-кB. Oncotarget 2016;7:31663-80.

21. Ankers JM, Awais R, Jones NA, Boyd J, Ryan S, Adamson AD, et al. Dynamic NF-KB and E2F interactions control the priority and timing of inflammatory signalling and cell proliferation. Elife 2016;5:e10473.

22. Kim DH, Park MH, Choi YJ, Chung KW, Park CH, Jang EJ, et al. Molecular study of dietary heptadecane for the anti-inflammatory modulation of NF-KB in the aged kidney. PLoS One 2013; 8:e59316.

23. Carmichael J, DeGraff WG, Gazdar AF, Minna JD, Mitchell JB. Evaluation of a tetrazolium-based semiautomated colorimetric assay: assessment of chemosensitivity testing. Cancer Res 1987;47:
936-42.

24. Carrillo MC, Kanai S, Nokubo M, Kitani K. (-) deprenyl induces activities of both superoxide dismutase and catalase but not of glutathione peroxidase in the striatum of young male rats. Life Sci 1991:48:517-21.

25. Kim HS, Seo H, Yang C, Brunet JF, Kim KS. Noradrenergic-specific transcription of the dopamine beta-hydroxylase gene requires synergy of multiple cis-acting elements including at least two Phox2a-binding sites. J Neurosci 1998;18:8247-60.

26. Sánchez-Valle V, Valverde M, Carrizale L, Mejía J, Zepeta N, Rojas E. A metal mixture induces transformation upon antioxidant depletion in a hepatic cell line. Ann Hepatol 2013;12:315-24.

27. Priyanka HP, Bala P, Ankisettipalle S, ThyagaRajan S. Bacopa monnieri and L-deprenyl differentially enhance the activities of antioxidant enzymes and the expression of tyrosine hydroxylase and nerve growth factor via ERK $1 / 2$ and NF-KB pathways in the spleen of female wistar rats. Neurochem Res 2013;38:141-52.

28. Zelko IN, Mariani TJ, Folz RJ. Superoxide dismutase multigene family: a comparison of the CuZn-SOD (SOD1), Mn-SOD (SOD2), and EC-SOD (SOD3) gene structures, evolution, and expression. Free Radic Biol Med 2002;33:337-49.

29. Wang L, Yuan D, Zhang D, Zhang W, Liu C, Cheng H, et al. Ginsenoside re promotes nerve regeneration by facilitating the proliferation, differentiation and migration of schwann cells via the ERK- and JNK-dependent pathway in rat model of sciatic nerve crush injury. Cell Mol Neurobiol 2015;35:827-40. 